\title{
The Role of Economic Integration in Trade Openness: The Black Sea Economic Cooperation Organization Case
}

\author{
Prof. Dr. Sedat Murat (Istanbul University, Turkey) \\ Assoc. Prof. Dr. Sefer Şener (Istanbul University, Turkey) \\ Dr. Burcu Kılınç Savrul (Canakkale Onsekiz Mart University, Turkey)
}

\begin{abstract}
Trade liberalization is one of the greatest economic arguments of the economics and it is claimed that trade openness is a crucial phenomenon for the well-being of nations since Adam Smith. Although various practices have been seen in different parts of the world in the history, from 1980s trade liberalization movements have been the dominant trend. However liberalization of trade in developing countries brought debates in economic literature and it is argued that open trade can have catastrophic effects instead of providing growth and welfare to the practitioner countries. In this study if The Black Sea Economic Cooperation Organization had contributed the member states to liberalize their trade has been investigated. The changes in the rates of inward and outward investment, import, export, population and labour force of the member countries during the establishment period of the Organization has been evaluated. The data is collected from Worldbank National Accounts Database, IMF World Economic Outlook and Balance of Payments Database and UNCTAD. The results of the study has shown that although the establishment of the organization had positive effect on investment and trade flows of the countries, it had no effect on labour flows of the member states.
\end{abstract}

\section{Introduction}

All economies are increasingly open in today's economic environment of globalization. International trade plays a vital role in shaping economic and social performance and prospects of countries around the world, especially those of developing countries. Without trade, the economic and social condition of the country cannot progress. However, the contribution of trade to development depends a great deal with the context in which it works and the objectives it serves. In recent years, many developing countries, have stepped upon unilateral trade liberalization, with very limited results at best in terms of increased growth and development (UNCTAD, 2004).

Although general consensus argue that free trade has benefits, in 1980s many developing country had economic instability and had to struggle with financial and economic crises due to structural unemployment caused by the removal of trade barriers, domestic economic instability from international trade cycles and pressures created by global economic competition. Today the global economic competition continues through economic integrations in commercial sense. In this perspective, these integrations can help developing countries liberalize the trade without facing the issues mentioned above alone.

Although the countries in Black Sea region had strategic advantages such as having mass raw materials and oil resources, being settled on crossroads between Asia and Europe and having relatively young and ample labour force; social and political conflicts, cold war and impact of planned economic system keep the region from bring its strength out. Just as the rest of the developing world many countries of the region gave emphasis on open trade in 1980s and 1990s. In this framework the study investigates whether or how the Black Sea Economic Cooperation established in the same period had affected the member countries opening their trade and investment to global markets.

\section{Trade Openness}

Economic theory propose that international trade improves resource allocation, lowers prices for consumers, and leads to a more efficient production. An open trade regime is also believed to encourage the integration of the economy into the global system and imports of modern technology, which results in productivity improvements (Montalbano, 2011: 1489).

Trying to ease to exchange goods and services, capital, labour, information, and ideas across the borders is known as trade openness. The main goal of these efforts is to integrate economies and societies at global level. Openness is known to help movement of resources from developed to developing economies and contributed to technological advancement. Today economies are reaping fruits of openness due to the diffusion and absorption of technology. Improvement of transportation and communication has helped rediscover the opportunities at global level and identify new international markets for exchange of goods and services. Openness allows foreign direct investment in host country which contributes to economic growth by supplementing domestic capital, redefining the concept of economic efficiency, boosting productivity and bringing the world together (Shahbaz, 2012: 2325). 
Trade openness has emerged as the main argument among economists and policy makers in explaining the growth phenomena in developing countries. Besides, due to continuous interest on the issue, new methods were also proposed. The positive contribution of trade openness towards growth stemmed from the notion that liberalization increases specialization and division of labour thus improving productivity and export capability as well as economic performance (Chandran and Munusamy, 2009: 638). In addition, with greater efficiency as a result of trade openness, many of the developing countries followed suit with the export-led strategies. It is widely recognized that trade openness has a positive effect towards economic growth. It is found that countries with more trade openness relatively outperformed the countries, with less openness (World Bank, 1993). Accordingly the dimensions that trade openness can contribute an economy can be seen in Figure 1.

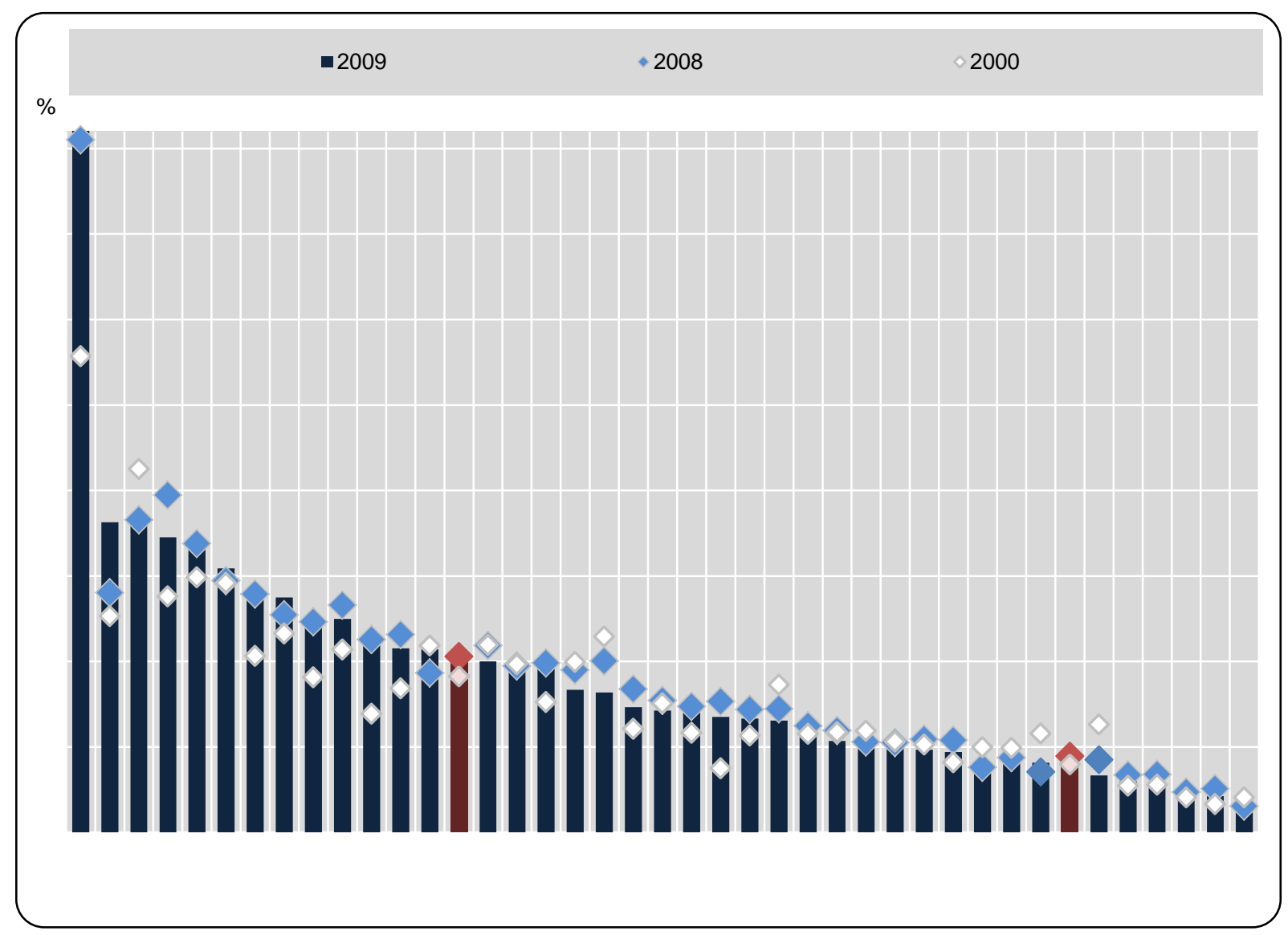

Figure 1: Average of Exports and Imports of Services as a Percentage of GDP, 2000, 2008 and 2009 Source: OECD, National Accounts Database, June 2011; International Monetary Fund, World Economic Outlook and Balance of Payments Databases, May 2011

The OECD and IMF figures displaying trade flows as a percentage of GDP between 2000 and 2009 show that the relative importance of trade. Trade flow of OECD average has increased 10 percent from 2000 to 2008 and more in some countries. After widespread increases in the trade-to-GDP ratio between 2000 and 2008, all OECD countries and the BRIICS (Brazil, the Russian Federation, India, Indonesia, China, South Africa) saw a drop in this ratio between 2008 and 2009, mostly owing to significant drops in trade in goods due to the Economic and Financial Crisis of 2008. In many countries it fell below the ratio recorded at the -beginning of the decade. In 2009 , the average trade-to-GDP ratio of OECD countries was about $41 \%$, nearly double that of the BRIICS. In part, this is because the OECD includes many relatively small economies. Considering the OECD as a single aggregate, with high weights for Japan and the United States, would give a ratio closer to $20 \%$, similar to that of the BRIICS.

Despite significant falls in 2009, trade in goods remains the principal channel for economic integration for many countries. It represents, on average, three times the value of trade in services in OECD countries and more than four times in the BRIICS. However, the crisis had a much smaller impact on trade in services than in goods; few countries experienced significant falls in the ratio of trade in services to GDP.

Free and open markets may influence long-run economic growth in many different specific ways in a dynamic world. One path comes from the expanding the opportunities of firms to realize more fully scale economies and greater efficiency in investment. Increased competition, resulting from reduced barriers for foreign competitors, serves to limit the market power of domestic imperfectly competitive markets, mandates efficiency, and delivers 
a greater variety of both finished products and intermediate inputs to consumers and industry, respectively. A different path for growth through trade liberalization stems from the transfer of ideas and the ability of domestic industries to utilize imported intermediate inputs that benefit from new technologies in the world economy. Repeated and sustained interaction through international trade facilitates the ability of domestic producers to adopt foreign knowledge in their own production (Skipton, 2007).

The economic well being of a country is associated closely to the availability of resources and the productivity of its workforce. Trade operates in a diversify ways to sustain the economic development process. It enhances competition and the linked thrust to innovation and specialization, and it provides a significant channel for international technology transfer (Mazumder, 2008: 9). In this respect, opening up their economies to the global economy has been essential in enabling many developing countries to develop competitive advantages in the manufacture of certain products.

Although general consensus argue that free trade has benefits, there are a number of arguments put forward by lobby groups and protestors who oppose free trade and trade liberalisation. These can be listed as follows (HSC, 1999):

- With the removal of trade barriers, structural unemployment may occur in the short term. This can impact upon large numbers of workers, their families and local economies.

- Increased domestic economic instability from international trade cycles, as economies become dependent on global markets. This means that businesses, employees and consumers are more vulnerable to downturns in the economies of trading partners.

- International markets are not a level playing field as countries with surplus products may dump them on world markets at below cost. Some efficient industries may find it difficult to compete for long periods under such conditions.

- Developing or new industries may find it difficult to become established in a competitive environment with no short-term protection policies by governments, according to the infant industries argument. It is difficult to develop economies of scale in the face of competition from large foreign TNCs.

1980s witnessed many cases that various developing country had economic instability and had to struggle with financial and economic crises after they liberalized their markets before they consolidated their economic system. In this context it is questionable whether instead of confronting global competition alone, accessing an economic integration may protect developing countries from global pressure.

\section{Economic Integrations and Trade Openness}

The elimination of barriers to global trade also meant the removal of barriers to global competition. Although unfavourable impacts of getting into global competition are obvious, inclination towards global trade is questionable. Despite the negative experiences, the reasons countries have a positive look on the global trade can be summed as (Gürak, 2006: 285-286);

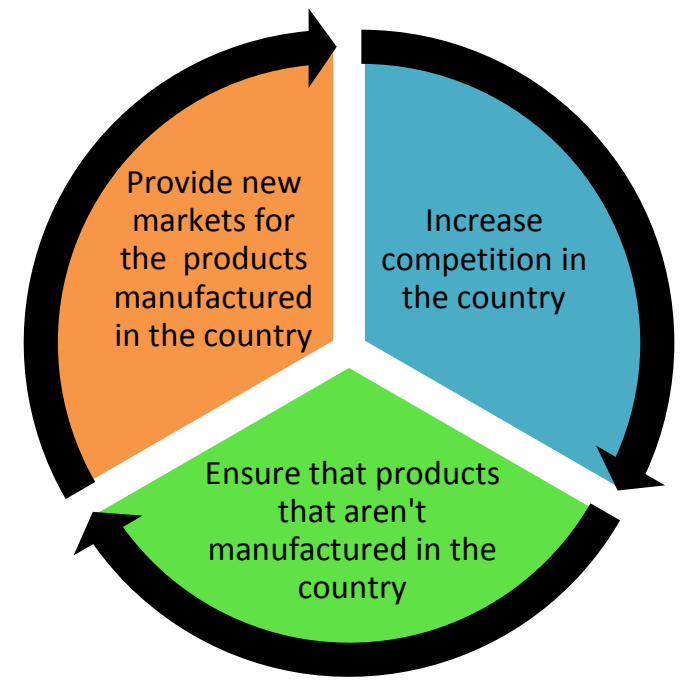

In this respect sooner or later liberalization case came to agenda of any country which seek for economic development and stability. Liberalization of trade has been one of the most important economic arguments of the economics and it has been suggested that free trade would increase the well-being of nations since Adam Smith. In this context, the ultimate goal of developing countries is to outsource. Trade liberalization movements which accelerated through the activities of The General Agreement on Tariffs and Trade (GATT) and the its modern- 
day equivalent World Trade Organization (WTO), continues with the recent activities of accelerating economic integration trend (İncekara and Savrul, 2011: 11-12).

International economic integrations emerge often based on liberalization of trade between the countries in the same geographical area. Although they are discussed at a theoretical level for a long time, after the Second World War, practice opportunities came out for economic integrations and many of them have been established in different areas of the world between both developed and less developed countries (Güran, 1997: 12). The resulting integration of the world economy has raised living standards around the world. Most developing countries have shared in this prosperity; in some, incomes have risen dramatically. As a group, developing countries have become much more important in world trade, they now account for one-third of world trade, up from about a quarter in the early 1970s. Many developing countries have substantially increased their exports of manufactures and services relative to traditional commodity exports: manufactures have risen to 80 percent of developing country exports. Moreover, trade between developing countries has grown rapidly, with 40 percent of their exports now going to other developing countries (IMF, 2001)

In this perspective, since the emergence of the concept of economic integration, the reasons the countries find economic integration movements appealing can be summarized as follows (İncekara, 1995: 266);

- Increasing economic potential of a country by expanding the production capacity of the country, increasing efficiency and consequently maximizing social well-being. These objectives can be reached through joining economic integrations which can expand market volume.

- In recent years developed countries' imparting momentum to free trade has led to an increase in regional trade integrations. Trying to achieve greater competitiveness against non-regional countries or blocks and strategies such as taking part in international policy are the major causes of the emergence of economic integrations.

- Another reason of emergence of economic integrations is to eliminate the potential disputes between the neighbouring countries that have to live together. Instead of having conflicts, countries involved in integration can eliminate potential conflicts and establish political stability by uniting their capabilities.

Economic integrations between developing countries can also stimulate foreign trade by constituting some cross-border investment projects. Starting an industrial joint venture in a country which has the most favourable position in the integration to produce any property can meet the needs of all member states which in result solving the issue of scale (Sabir, 2010) which bring out social cooperation possibilities besides the economic ones which is essential for a sound economic integration.

\section{Organization of the Black Sea Economic Cooperation}

The Black Sea area between the crossroads of Asia and Europe where people of different nationalities, trades, cultures and religions blended to each other, has been the cradle of different civilizations since ancient times. It witnessed periods of peace and tranquillity were followed by protracted conflicts and wars. But even in that climate the Black Sea area was well known for its developed trade relations and contacts. Attempts were undertaken to build bridges of rapprochement. It is sufficient to mention the famous Silk Road which linked the countries of Europe and Asia. A valuable experience of contact among the peoples of the two continents as well as of the cohabitation and mutual enrichment of different cultures has been accumulated (Photius Coutsoukis, 2013).

Only in the last decade of the twentieth century however, when the atmosphere of the cold war, suspicion and mistrust has receded, have the countries of the Black Sea area been able to undertake bold steps in that direction. They could come together and decide how, in the age of the globalization of economies, valuable assets in their possession, such as geographical proximity, common history, cultural bonds and the interdependence of their national economies could be efficiently employed for mutual benefit and prosperity (Lupu, 2006: 134) and decided to start a regular dialogue leading them to launch the Black Sea Economic Co-operation (BSEC) in 1992 in Istanbul. BSEC permanent members are the three EU MS (Bulgaria, Greece and Romania), Black Sea Synergy's countries (Armenia, Azerbaijan, Georgia, Republic of Moldova, Russia, Turkey and Ukraine) plus Albania and Serbia (European Commission, 2013). BSEC received the status of full international organization in 1999. BSEC promotes and coordinates regional cooperation in a wide range of areas - tourism, trade, banking, communications, energy, transport, agriculture, health, environmental protection, combating organized crime and others (Ministry of Economy and Energy of the Republic of Bulgaria, 2013).

BSEC is found as a unique and promising model of multilateral political and economic initiative aimed at fostering interaction and harmony among the Member States, as well as to ensure peace, stability and prosperity encouraging friendly and good-neighbourly relations in the Black Sea region which covers a geography encompassing the territories of the Black Sea littoral States, the Balkans and the Caucasus with an area of nearly 20 million square kilometres. BSEC region is located on two continents and it represents a region of some 350 
million people with a foreign trade capacity of over USD 300 billion annually (Republic of Turkey Ministry of Foreign Affairs, 2011).

The BSEC has undoubtedly succeeded in creating a framework for multilateral co-operation in an area with different geopolitical and economic realities and hence affected by great turmoil. In a region representing not only an area rich in oil and gas, but also a strategic corridor for the passage of raw materials between Asia and Europe, the organisation has especially committed itself to ensuring political stability and promoting the growth of trade. To this end, priority has been given to sectors such as energy, transport and telecommunications. However, acting according to perspectives of sustainable development, special attention has also been given to issues concerning environmental protection and especially the marine ecosystem. The presence within the organisation of EU Member States and candidates has contributed to turning the objectives of good governance, democracy and protection of human rights into topics for debate and exchange of opinions improving the regional political climate (International Democracy Watch, 2013; RhodesMRC, 2010).

\subsection{The Effect of BSEC on Trade Openness of The Member Countries}

A remarkable issue about the BSEC is that its establishment coincide with the economic liberalization movements of developing countries including the BSEC members. In this regard how the establishment of BSEC has affected the liberalization process of the member countries is a subject of matter.

Before looking into the BSEC it would be useful to query in what channels an economic integration basically affect member countries. Although many reasons lie behind the activities of economic integrations, officially recognized key objectives can be summed up as (Schiff and Winters, 2003: 6-10);

- promote domestic and foreign investments,

- $\quad$ increase their competitiveness through access to broader markets

- $\quad$ provide stable access to foreign technology and investments

In this perspective it would be meaningful to compare the changes in trade investment and labour figures of the member countries to evaluate the effect of establishment of BSEC.

\subsection{Trade, Foreign Direct Investment and Labour Force Trends in BSEC}

The advantages enjoyed by countries engaged in mutual free trades can be summarized as follows (EconomyWatch, 2010):

- Considerable reduction in the cost of transportation, especially with the development of containerization with respect to overseas ocean shipments,

- Decrease or abolition of control over capital and the capital market,

- Formation of free zones for carrying out commercial activities, against payment of little or no tariffs at all,

- Decrease, abolition or synchronization of subsidies in domestic trades,

- Decrease or abolition of every kind of tariffs.

Consequently although it isn't the sole goal, mutual free trade is one of the leading purposes of the Cooperation. The changes in the import and export flows of the BSEC is shown in Figure 2.

Goods and Services Trade Openness data show that both import and export volume of BSEC countries were about $20 \%$ of their GDP on the average in 1980s and the figures fell below $15 \%$ in the beginning of 1990s. The period after 1990 they had a sharp increase in their trade volume and the figures doubled in the following ten years. The period after 2000 was a recession period almost for the whole world and the region has been affected from the process. Although the Crisis slightly affected trade in the region in 2008, it quickly recovered and returned to the level of pre-crisis period.

Evaluating the figures although it is hard to say the establishment of the BSEC is the sole reason of the increase in the trade volume of the member countries after 1990, it can be concluded that the organization has contributed development of trade of the member countries and provided a steady increase for a period.

Capital accumulation is regarded as the basic dynamic of economic development by economists. In other words, failure of capital accumulation is the biggest cause of economic lag in some countries. It is apparent that developing countries need too much capital for, transforming their economic structure to be able to reach the level of developed countries (Kar and Tatlısöz, 2008: 437). Another aspect that economic integrations promote member countries is rise in their capital accumulation through foreign investment.

Foreign direct investment helps developing countries to confront the international competition by boosting their economy, increasing productivity and export capacity. For developing countries, one of the most important benefits of foreign investment is the contributions to eliminate deficits. Foreign direct investments reflect positively to one-time balance sheet of the host country. Another positive effect is that they contribute to development of exports of the host country via operations of the companies with foreign investment in foreign markets (Candemir, 2007). The figures of foreign direct investment flows of BSEC countries before and after the establishment of the Organization is as follows; 


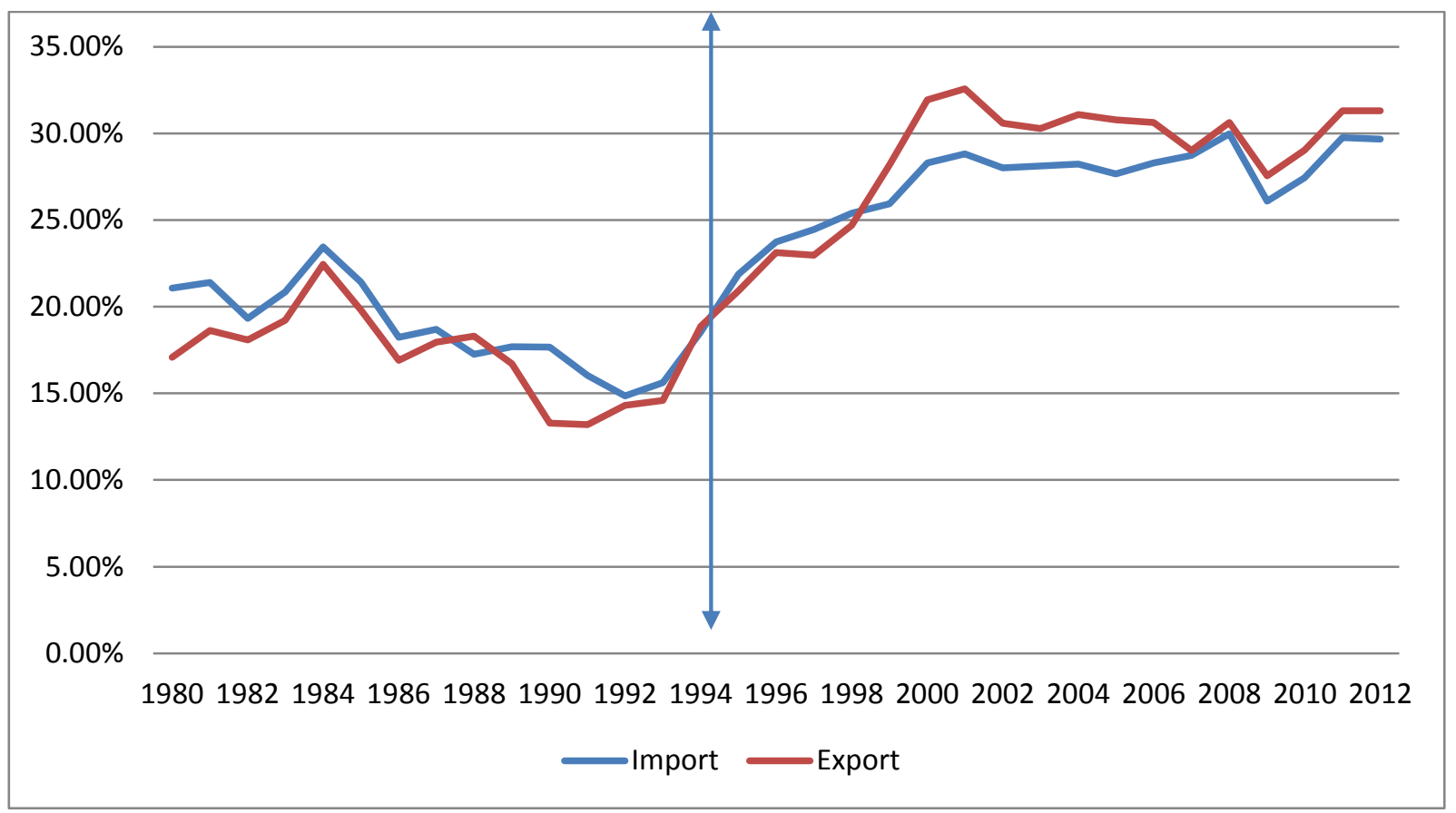

Figure 2: Goods and Services Trade Openness in BSEC, Percentage of Gross Domestic Product, 1980-2012 Source: UNCTAD. (2013), UNCTADstat.

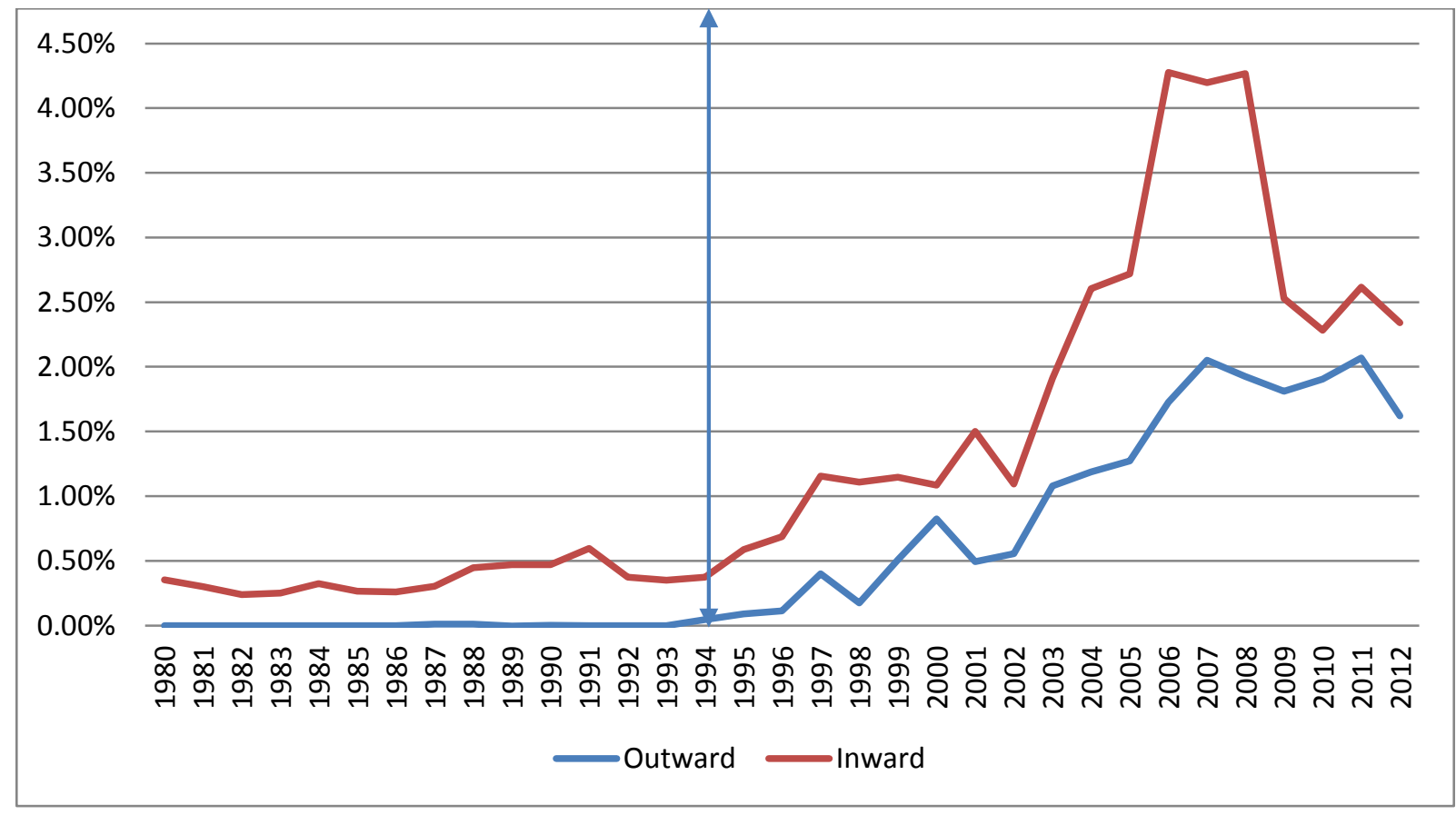

Figure 3: Inward and Outward Foreign Direct Investment Flows in BSEC, \% of GDP, 1980-2012 Source: UNCTAD. (2013), UNCTADstat.

Since the beginning of 1990 the foreign direct investment flows of region were at insignificant levels. Between 1980 and 1990 incoming investment flows were below 0,5\% of GDP and outgoing flows had negative figures. Distinct from trade figures, foreign direct investment figures display that the establishment of BSEC had a direct positive impact on the investment flows the member countries. The establishment of the organization accelerated both incoming and outgoing investment flows. Incoming investment ratio reached to \%1 in 1996, 2,5 in 2003 and went behind $4 \%$ in 2006. Since the BSEC is formed of developing countries the outgoing investment level stayed fairly low compared to the incoming one. However the BSEC contributed the outgoing investment flows in a manner too and the outgoing investment rate changed to positive by the establishment of the organization and reached to \%1 of GDP in 2003 and \%2 in 2006.

It is apparent that the impact of Financial and Economic Crisis of 2008 on direct foreign investment flows of the BSEC has been more severe than trade. The BSEC members lost almost half of their incoming investment 
flows because most of the investors were the western European countries which were badly affected by the crisis. On the other hand the effect of the crisis weren't so intense on outgoing capital flows and it almost maintained the pre-crisis condition.

Integrations are also expected to flourish the member countries with labour flows. When markets are open and are free from all barriers then private investors get better opportunity with reduced uncertainty whereas previous barriers might have restricted their business. Private investment brings intellectual capital and technology, and can also push other aspect of social infrastructure in a positive direction. The change in population and labour force of the BSEC countries is summed up in Figure 4.

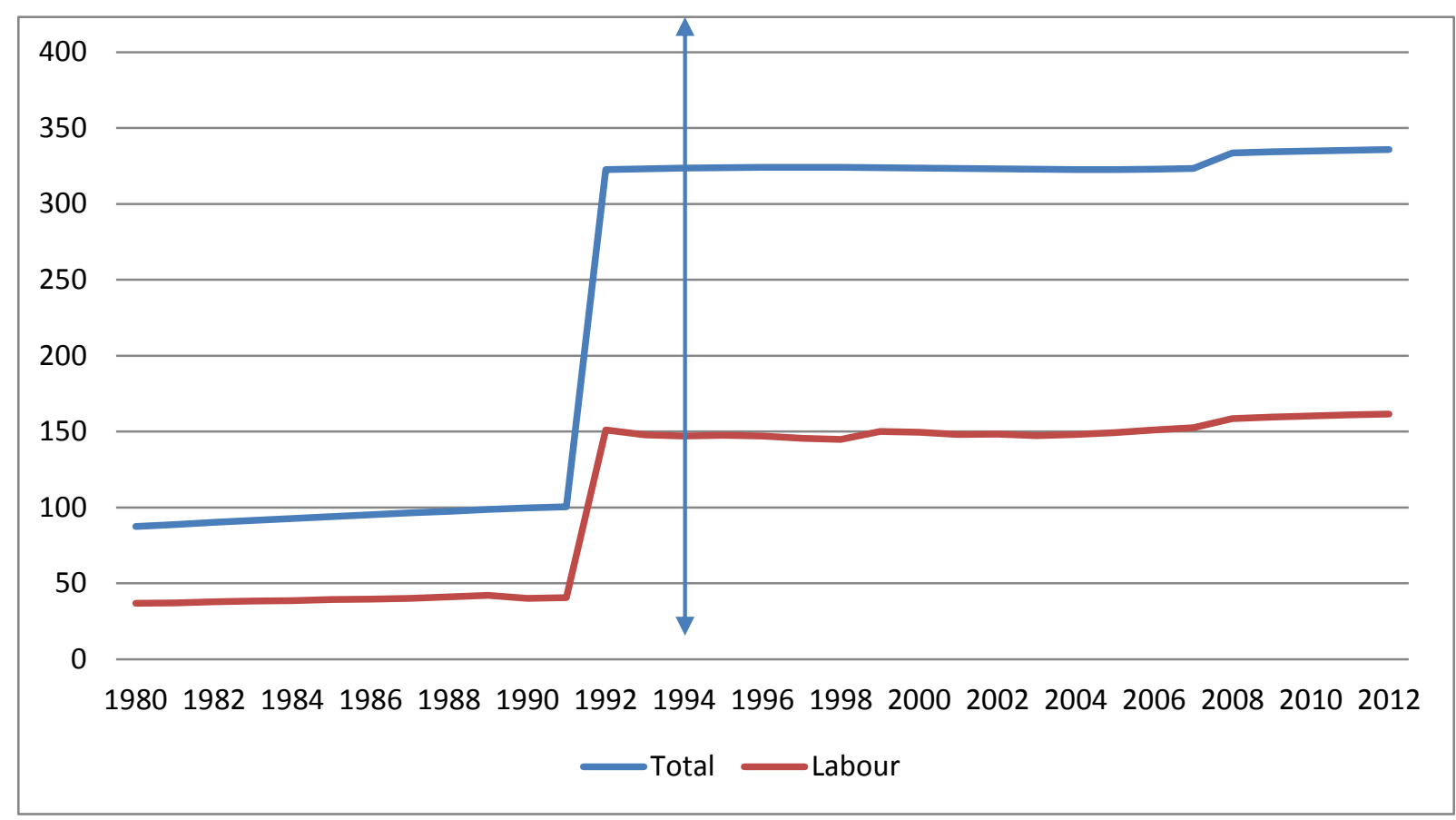

Figure 4: Total Population and Labour Force in BSEC, Million, 1980- 2012 Source: UNCTAD. (2013), UNCTADstat.

Total population of the member states of BSEC has been about 100 million and total labour force has been below 50 million between 1980 and 1991. In 1992 due to the collapse of Soviet Union the population tripled and rose to 322 million people. Same way the labour force exceeded 150 million. The figures increased not insignificantly in the following period and the population reached only 335 million while the total labour force reaching 161 million people. Evaluating the figures it can be said that the establishment of the BSEC had no impact on the increase of population and labour force of the member countries. Since the Organization hasn't reached to level of full economic union, free movement of people within the Organization. As a result establishment of BSEC had no or little influence on labour or population movements. Moreover, although BSEC had helped job creation in the Organization through direct investment flows its extend is away from attracting exterritorial labour to the region.

\section{Conclusion}

The evidences are clear that opening economies to trade and investment with the rest of the world are necessary for sustained economic growth. The experiences has shown that without being open to the rest of the world no country in recent decades has achieved economic success and provided acceptable living standards to its people. In contrast, opening trade and foreign direct investment have been an important element in the economic success of many countries. Integration into the world economy has proven a powerful means for countries to promote economic growth, development, and poverty reduction. Over the past 20 years, the growth of world trade has averaged 6 percent per year, twice as fast as world output. But trade has been an engine of growth for much longer.

Although general consensus argue that free trade has benefits, in 1980s many developing country had economic instability and had to struggle with financial and economic crises due to structural unemployment caused by the removal of trade barriers, domestic economic instability from international trade cycles and pressures created by global economic competition. Today the global economic competition continues through economic integrations in commercial sense. In this perspective, these integrations can help developing countries liberalize the trade without facing the issues mentioned above alone. 
In this study the effect of establishment of the Black Sea Economic Cooperation on trade and investment liberalization process of the member countries has been examined. According as the primary effects of the economic integrations on member countries, changes in import, export, inward and outward foreign direct investment flows and labour force movements of the Organization have been evaluated. The results of the study has shown that although the establishment of the Organization slightly contributed development of trade of the member countries and provided a steady increase for a period, it has been fairly effective in development of foreign direct investment flows in the region however because the Organization doesn't allow free movement of people within the Organization such as EU BSEC had no or little influence on labour or population movements in the region.

\section{References}

- Candemir, Aykan. (2007), "Doğrudan Yabancı Sermaye Yatırımlarının Ekonomık Büyüme ve İstihdam Üzerindeki Etkileri”, İşveren, TISK, May, <http://tiskweb.com/isveren_sayfa.asp?yazi_id=1721 \&id=87>, (29.05.2013).

- Chandran, V.G.R.; Munusamy. (2009), "Trade openness and manufacturing growth in Malaysia", Journal of Policy Modeling, Vol. 31, Issue 5, September-October, 637-647.

- Economy Watch. (2010), "Effects of Globalization", <http://www.economywatch.com/economicstheory/globalization/effects.html> (02.06.2012).

- $\quad$ European Commission. (2013), "Black Sea Economic Cooperation Organisation (BSEC) Ministerial Meeting, Odessa, Ukraine", <

http://ec.europa.eu/information_society/newsroom/cf/mare/itemdetail.cfm?item_id=11179>, (27.05.2013).

- Gürak, Hasan (2006), "Ekonomik Büyüme ve Küresel Ekonomi", Ekin Yayınevi, Bursa.

- $\quad$ HSC. (1999), "Free Trade and Protection: Advantages and Disadvantages of Free Trade", Charles Sturd University, < http://hsc.csu.edu.au/economics/global_economy/tut7/Tutorial7.html>, (27.05.2013).

- Güran, Nevzat; Aktürk, İsmail. (1997), "Uluslararası İktisadi Kuruluşlar", Anadolu Matbaacılık, İzmir.

- İncekara, A., Savrul, M. (2011), "Küreselleşme, Büyüme ve Ekonomik Entegrasyonlar: Türkiye Açısından Bir Değerlendirme", Iktisat Fakültesi Mecmuası, Cilt: 61, Sayı:2, 3-22.

- İ́ncekara, Ahmet. (1995), "Globalleşme ve Bölgeselleşme Sürecinde Nafta ve Etkileri", İstanbul Ticaret Odas1, Yayın No:195-14, İstanbul.

- IMF. (2001), "Global Trade Liberalization and the Developing Countries", <http://www.imf.org/external/np/exr/ib/2001/110801.htm>, (29.05.2013).

- International Democracy Watch. (2013), "Organization of the Black Sea Economic Cooperation", <http://www.internationaldemocracywatch.org/index.php/organization-of-the-black-sea-economiccooperation>, (25.05.2013).

- International Monetary Fund. (2013), "World Economic Outlook and Balance of Payments Databases", May 2011.

- Kar, Muhsin; Tatlısöz, Fatma. (2008), “Türkiye'de Doğrudan Yabanci Sermaye Hareketlerini Belirleyen Faktörlerin Ekonometrik Analizi”, KMU IIBF Dergisi, Year.10, No.14, December.

- Lupu, Gratian. (2006). "EU, BSEC and Energy Co Operation", Sfera Politicii, 125/2006, 134-140.

- Mazumder, Rabin. (2008), "Trade Liberalization \& WTO: Impact on Developing Countries", January 16, < http://ssrn.com/abstract=1084394>, (26.05.2013).

- $\quad$ Ministry of Economy and Energy of the Republic of Bulgaria. (2013), "Black Sea Economic Cooperation Organization (BSEC)", <http://www.mi.government.bg/en/themes/black-sea-economiccooperation-organiz ation-bsec-298-0.html $>$, (24.05.2013).

- Montalbano, Pierluigi, 2011. "Trade Openness and Developing Countries' Vulnerability: Concepts, Misconceptions, and Directions for Research," World Development, Elsevier, Vol. 39(9), 1489-1502, September.

- $\quad$ OECD. (2013), "National Accounts Database", June 2011.

- Photius Coutsoukis. (2013), "Black Sea Economic Cooperation Pact", <http://www.photius.com/bsec/ bsec.html>, (24.05.2013).

- $\quad$ Republic of Turkey Ministry of Foreign Affairs. (2011), "The Black Sea Economic Cooperation Organization (BSEC)", <http://www.mfa.gov.tr/the-black-sea-economic-cooperation-organization_bsec_.en.mfa>, (25.05.2013). 
- RhodesMRC. (2010), Black Sea Economic Co-operation, <http://www.rhodesmrc.org/2010/bsec.php>, (27.05.2013).

- Sabır, Hasan. (2010), "Gelişmekte Olan Ülkeler Arasında Ekonomik Entegrasyon: Mercosur Örneği", DTM <http://www.dtm.gov.tr/dtmadmin/upload/EAD/TanitimKoordinasyonDb/gelismekte.doc〉, (28.12.2010).

- $\quad$ Schiff, Maurice; Winters, L. A. (2003), "Regional Integration and Development", Worldbank and Oxford, Washington.

- Shahbaz, Muhammad. 2012) "Does trade openness affect long run growth? Cointegration, causality and forecast error variance decomposition tests for Pakistan", Economic Modelling, Vol. 29, Issue 6, November, 2325-2339.

- $\quad$ Skipton, Chuck. (2007), "Trade Openness, Investment, and Long-Run Economic Growth", '07- '08 Southern Economics Association (SEA) Meetings, New Orleans, La. November 18-21, 2007.

- UNCTAD. (2013), UNCTADstat.

- UNCTAD. (2004), "The Least Developed Countries Report 2004", United Nations Publications, Switzerland.

- World Bank. (1993), "The East Asian miracle: Economic Growth And Public Policy", Oxford University Press, New York. 